Since the above has been in type we have received the report of the annual general meeting of the Society, held in the great hall of the Engineering College of Tokio on January 23, amongst those present being some of the most prominent members of the Japanese Government, and many representatives of foreign Powers in Japan. The annual report stated that the Society now numbers over 6000 members, scattered over the various provinces of the Empire. A proposition having for its aim the retention of the old syllabary system of spelling, was rejected by a large majority in favour of phonetic simplicity, as above described. The Minister for Foreign Affairs, Count Inoue, delivered a speech, in which, viewing the aims, methods, and probable future of the Society from a great variety of standpoints, he expressed his complete sympathy with the movement. The British Envoy, in describing the objects of the Association, said :"We aim at nothing less than one of the greatest changes ever yet made in the history of literature, or indeed, I may say, of the world. We hope to bring the thoughts of a nation of $37,000,000$ into closer communion and intercourse with the thoughts of the rest of the world, and by freeing memory from the task of learning many thousands of characters, the sense of which can be satisfactorily rendered by a couple of dozen letters, to give the intellect some leisure to acquire the many and varied branches of learning which the necessities of modern civilisation render so important to us all."

\section{THE SURVEY OF INDIA ${ }^{1}$}

II.

$\mathrm{N}$ our first notice we reviewed the principal topographical and cadastral operations. We have now to review the interesting information regarding the physiography of the localities of operation and other subjects which is scattered over the Report, but chiefly in the appendixes.

The Andaman Islands wera being brought under survey for the first time; they form a portion of the belt of islands extending from the south-west point of the Burman mainland to the north-west point of the great Island of Sumatra, which are all that is now left of what was probably once a long, tapering off-shoot from the Asiatic continent, such as we still have in the Malayan Peninsula. These islands became of interest to the Government of India only of late years, when a convict settlement was established at Port Blair, on the South Andaman Island; but as yet little intercourse has been established with the inhabitants, who are wild and barbarous aboriginal Negritos with very dark skins and of very small stature. They are said to consist of nine distinct tribes known as Akas, which occupy separate islands and speak different dialects. Our influence has been most operative on the Aka-Bojigngiji, who are settled nearest Port Blair, and our relations with some of the other tribes are said to be on a fairly friendly footing, but very little is known about them, and nothing of the interior of the islands which they inhabit.

The Aka-Járawas, who occupy the Little Andaman, have ever been openly hostile; they are professional wreckers whom it has been necessary to punish on more than one occasion for barbarities perpetrated on shipwrecked crews, but they still retain their reputation for treachery and cruelty, and hold aloof from friendly intercourse ; of late years they have been visited annually by the Chief Commissioner, and presents have been made to them with a view to bringing about more amicable relations, but they have been known to accept the proffered presents and then attack the bearers on their way back to their boats; their language is said to be unintelligible to the anglicised or I "General Report on the Operations of the Survey of India Department, administered under the Government of India during 1883-84." Prepare under the direction of Col. G. C. De Pree, S.C., Surveyor-General of India. Continued from p. 444 . tamed Andamanese, who are employed as a go-between. The Survey officers landed on the island and deposited presents on the beach, and then retired to their boats; the Járawas advanced and appropriated the presents somewhat sulkily and retired into their forests, and consequently nothing could be done with them; but their dwellingplaces were entered and examined by the surveyors in their absence. These were found to be substantial, wellbuilt huts, affording shelter for from 30 to 4 opeople, circular, dome-shaped, about 60 feet in diameter, and rising to a height of some 35 feet in the centre; the dome was thatched, and supported on long poles set up in three concentric circles within the hut. Small cots and a rockingcradle were found inside ; and all round the interior pigs' skulls, beautifully cleaned and neatly bound up, were closely arranged about three feet from the ground.

Barren Island (lat. $12^{\circ} 15^{\prime}$ by long. $93^{\circ} 50^{\prime}$ ) and the Island of Narcondam ( $13^{\circ} 26^{\prime}$ by $94^{\circ} 16^{\prime}$ ) were visited and surveyed by Capt. Hobday, whose exquisitely shaded maps of these interesting volcanic islands are published with his report Barren Island is circular in shape with a diameter of 2 miles and an area of $3^{\circ} 07$ square miles. Its principal features are a main crater and an inner cone. The main crater is elliptical in shape, with axes of $\mathrm{I} \frac{1}{2}$ and $I$ mile, the walls rising to a height of I 158 feet above the sea-level on the south-east, and sinking down to the sea on the northwest ; the cone is about half a mile in diameter at its base, and rises IOI 5 feet above the sea, terminating in a small elliptical crater, with axes of 300 and 190 feet and a maximum depth of 74 feet. Steam and smoke were issuing from the highest point of the cone; sulphur was found in large quantities near the vent, at a temperature sufficiently high to be felt through the boots. There was evidence of three distinct outbursts of lava on the sides of the cone, half-way up ; the slopes were coated with fine volcanic ash, which made the ascent very laborious; loose cinders and scoriæ of various sizes lay heaped together in confused masses around the base, amid which occasional tongues of alluvial soil, overgrown with thick grass, were found jutting from the inner slopes of the main crater; the outer slopes were covered with thick vegetation, the principal tree being a species of fig. The island was infested with rats, which had not yet learnt to become shy of man, and were readily knocked over with sticks; bats and large crabs were found on the summit of the main crater. The outer slopes of the main crater would, if prolonged, meet in a point immediately above the present apex of the cone; thus it is conjectured that the crater was originally a true cone rising to about twice its present height, and that the upper portion has been carried away by a violent eruption, such as recently occurred at Krakatão, leaving the present truncated crater. The volcano is known to have been in an active state towards the end of the last century; since then it has been gradually cooling, and the temperature of a hot spring on the beach was found to be considerably less than it had been when measured by previous visitors.

The Island of Narcondam is about $2 \frac{1}{2}$ miles in length by $1 \frac{1}{4}$ in breadth, and rises to a height of 2330 feet above the sea ; it is composed of trachytic lava, but no trace of any crater was discerned. The slopes were covered with dense forest, but water was not found anywhere ; flocks of hornbills or toucans, uttering a peculiarly shrill note, followed the surveyors on their way to and from the summit; and a large iguana, with long prehensile claws, was captured and sent to the Museum at Calcutta.

In Assam a raid of the semi-savage Akas who inhabit the hills on the borders of Tezpur and Lakhimpur, led to the acquisition of some new geography by Colonel Woodthorpe and a party of surveyors who accompanied the troops which were sent to recover the British subjects who had been captured by the Akas and carried away into their hills. The country of the Daphlas was crossed, when a river, never before heard of, the Kaneng, was discovered 
and proved to be the most important of all the affluents of the Baroli ; it drains much of the area which has hitherto been assigned to the Khru. Colonel Woodthorpe maintains that some confusion appears to have existed in the public mind as to the proper application of the names Abor and Daphla, for whereas it is believed that "the Daphlas always tattoo but the Abors never," just the reverse is the case. "Abor" is, however, a very vague appellative, and among the Assamese themselves means only a "foreigner." It is applied equally to tribes in the Aka, Daphla, Miri, Mishmi, and Naga Hills, and is only acknowledged by the so-called Abors themselves out of deference to the isnorance of those who, they believe, would fail to recoznise them under any other name.

The survey of Independent Sikkim, in which Captain Harman's iife was nobly sacrificed, has now been completcd by his quondam assistant Mr. Robert. Returning from the northern frontiers of Sikkim, Mr. Robert has brought the unlooked-for intelligence that there are no great glaciers in the valleys to the north-east of Kinchinjinga, though situated on the shady side of peaks and ridges ascending as high as 28,000 feet, and nowhere under 20,000 feet; masses of glacial ice and névé skirt the lower slopes of the mountains, but without protruding into the valleys, and as a rule the enormous mass of snow deposited on these mountains--which are among the highest on the surface of the earth -is either evaporated where it falls or is melted and carried off by the Lichen and other feeders of the Teesta, without having first passed into the state of glaciers such as pervade the entire length of many of the valleys of the North-West Himalayas, near the junction with the Hindu Kush Range, where the mountains are lower, but the annual rainfall is much less.

The Survey operations confirm the general accuracy of the admirable sketch-map constructed by Sir Joseph Hooker upwards of thirty years previously, which has been our only reliable map of Sikkim up to the present time, and which still represents the limits of the geographical knowledge acquired by Europeans beyond the frontiers of Siklkim; the officers of the Survey have not been able to penetrate further north than he did, nor do more than see, as he saw, without fixing, the peaks of the great Tibetan ranges beyond; all new geography in Tibet is wholly due to the native explorers.

Colonel Tannergives an interesting account of the journey of one of these explorers, " the Lama," through portions of Southern Tibet and the northern borders of Bhutan; an excellent map is attached in illustration. The Lama travelled round the entire circumference of the famous Yamdok Lake-lat. $20^{\circ}$ by long. $90^{\circ} 45^{\prime}$ - which was visited by D'Anville in 1735 and by Manning in $\mathrm{I} 8 \mathrm{I} \mathrm{J}$, and forms such a prominent object in all maps of Tibet; he found it considerably larger than has hitherto been conjectured, the circumference being 120 miles excluding and i 80 miles including the bends of the shore. There are numerous towns and villages on its banks, a large population, and much cultivation. It is sometimes called Piahte, or Pálti, after a neighbouring town, but most commonly the Yandok-tso or Scorpion Lake, because its shape resembles that of a scorpion ; the tail points eastwards towards the Karr-másing, "the starry plains," or "plains of heaven," a delightful and far-reaching extent of sward on which graze thousands of cattle, horses, and beasts of the chase; the two claws point to the west, and almost encircle a peninsular mountain tract, on which there are some villages and an important monastery. The south claw partially encircles an inner lake-the Dumu-tso-which is 500 feet higher than the main lake, and has a circumference of 24 miles, and is regarded by the Tibetans with great awe, fear, and superstition. There is an idea that some day Tibet is doomed to be flooded and all animal life destroyed by the overflow of this lake, and prayers are constantly being offered up in the surrounding monasteries to avert the catastrophe. Earthquakes, landslips, and convulsions, accompanied by subterraneous noises, are said to be of constant occurrence, and the waters are reputed to be steadily rising, notwithstanding the prayers constantly offered by the monks to turn away the wrath of the demon of Dumu-tso, who is believed to be confined below the waters.

The Yamdok Lake drains westwards into the Yarusanpo or Upper Brahmaputra River, through a valley which lies parallel to the river but slopes in the opposite direction. Colonel Tanner points out that this is a general feature in the drainage of Southern Tibet, all the principal feeders of the Sanpo running for the greater length of their courses in a contrary direction to the great river itself. The Lama was informed that the lake occasionally falls to so low a level that it receives water from the Sanpo, but this seems scarcely possible, for on the occasion of his visit it stood I600 feet above the Sanpo at the point of junction with the drainage channel--as shown by his boiling-point observations-and even then the flow of the current in the channel was not particularly remarkable. It not unfrequently happens in analysing the work of the native explorers that the facts deducible from their own observations, which they are taught to make accurately but not to reduce, prove some of the tales they have been told by the people of the country to be fictions.

To the south of the Yamdok the Lama discovered a new lake, called the Pho-mo-chang-thang (lit. man and wife of the high plain), at a height exceeding 16,000 feet, embosomed in lofty mountains and having no outlet. The range to its south is a portion of the great water-parting between India and Tibet; the Lama crossed it by the Menda Pass, i7,450 feet high, and then descended the north-west branch of the Lhobra River to Lhá-kbang Jong (lat. $28^{\circ} 5^{\prime}$, long. $91^{\circ} 5^{\prime}$, height 9500 feet), where he saw the Lhobra River flowing to the south towards Bhutan through a deep gorge. Colonel Tanner says this river must be one of the largest, if not the very largest, feeder of the Monas, but we know so little of Bhutan that it is hard to say which of the streams crossed lower down by Pemberton is the Lhobra. Leaving Lhá-kháng Jong the Lama ascended the north-east branch of the Lhobra River, and again crossing the great water-parting-at the Sharkha-leb Pass, 16,800 feet-returned to Tibet, his détour to the south having taken him over much ground that was entirely new to geography. Our limits do not allow us to devote more space to his travels, which are very interesting and valuable,--a satisfactory evidence of the advantages which the Indian Survey derives from its utilisation of Asiatic employés to explore regions into which Europeans are not allowed to penetrate.

Colonel Tanner is an artist as well as a geographer, and his reports contain much picturesque description, in addition to necessarily dry detail. He was employed for some years in the Western Himalayas, around Gilgit, and in the neighbourhood of several very high mountains, including the great Nanga Parbat and the sharp-pinnacled Rakiposhi; and he gives an interesting comparison of the aspects of these mountains with those of the Eastern Himalayas, showing that the latter are less striking, though they are the higher, and include Everest, 29,000 feet, the highest peak yet measured on the surface of the globe; their bases are more elevated, and thus the surfaces of snow which they expose to view rise into the sky to a less height above their surroundings. He says of Everest that the outline is rather tame than otherwise, and that Makalu-27,89o feet high, and 12 miles south-east of Everest-is the finest peak yet fixed in the Eastern Himalayas, with the exception of Kinchinjinga, 28,160 feet. The fact is that Everest lies some distance to the north of the main line of peaks, and the view of it from the southeast, south, south-west, and west-south-west is shut out by more prominent peaks which, though lower in height, are nearer the point of view accessible to Europeans, and are also less lowered by the earth's curvature than the more 
distant pinnacle. These peaks are frequently mistaken for Everest ; thus in the atlas accompanying the "Results of a Scientific Mission to India and High Asia " there is a large chromolithographed plate from a drawing by Hermann Schlagintweit of a mountain which he believed to be Everest; but the mountain is undoubtedly Makalu, as has recently been pointed out elsewhere. ${ }^{1}$ The best view of Everest from British territory is obtained at Sandakphu a well-known hill on the boundary between Nepal and Darjeeling ; but even there it is partly shut out from view by Makalu, which being exceedingly bold and picturesque in appearance generally comes in for more attention than its higher neighbour.

The pillars and posts marking the line of boundary between the Nepalese and the British territories, having in many instances been destroyed by wild animals or carried away by floods, survey operations have been undertaken, at the request of the Nepalese Government, with a view to relaying the line. This has afforded an opportunity of surveying the Sameswar Hills, the water-parting of which constitutes a portion of the boundary. A strip of the Nepalese territory which skirts the boundary has been sketched as far as circumstances would permit, and large errors in the topography of the tract, as laid down bitherto from native information, have been discovered and corrected. The Sameswar Hills are said to be very similar to the Siwalik Ranges, which the palæontological discoveries of Falconer, Cantley, and Baker have made so famous, excepting that the peaks are generally of less altitude, and the Pinus longifolia is almost entirely absent.

Major Holdich gives an account of the first ascent ever made by Europeans of the famous Takht-i-Suliman, or Throne of Solomon, the highest portion of the range of mountains on the western border of the valley of the Indus, which separates the highlands of South-Eastern Afghanistan from the plains of the Punjab. Viewed from these plains the Takht has the appearance of a ridge some 8 miles in length, much elevated above its surroundings, and with two culminating peaks at its northern and southern extremities,- apparently admirable points from whence to make a survey of the tract of country extenciing westwards almost as far as Candahar and Ghazni, of which very little is known. Lieutenant James Broadfoot, of the Bengal Engineers, travelled across it in 1839 , by the route from Ghazni to Deva Ismail Khan viâ the Ghwaleri Pass, of which he made a hurried sketch under great difficulties; and tine Zhob Valley to the south has been roughly mapped by a native explorer. But much more knowledge of the country was wanted, and this it was expected might be obtained by observations from the two great peaks of the Takht, the ascent of which had for many years been an object of laudable arnbition on the part of the Survey officers; they were greatly gratified when the Government authorised a survey expedition to be sent to the summit of the mountain, with a sufficient escort of troops to overcome any possible opposition. On reaching the summit the Takht was found to consist, not of a single ridge, but of two parallel ridges, with a plateau between, the highest point at the northern extremity ( 1,300 feet) being on the western ridge, while that on the southern extremity ( 11,070 feet) is on the eastern ridge, and is unfortunately shut out by the other from all view of Afghanistan. Thus the Takht was disappointing as a basis for distant geographical exploration; bit a good deal of valuable topography was secured of an important but little-known portion of the Sulimani Range, which constitutes the primary base for the defence of India from western aggression.

In Biluchistan Lieutenant the Honourable M. G. Talbot, R.E., and Lieutenant Wahab, R.E., made a valuable reconnaissance to the south-west of the little-known

"See "Notes on Mount Everest" in the Procedings of the Royal Geographical Society for February 1836. region which lies between Kelat, the capital, and the town of Gwadur, on the Persian Gulf; they worked over the Raskoh Ranges across the great plain of Kharan to the Lagar Koh and Koh-i-Sabz Ranges, and down to Panjgur. Much of the country traversed was a desert, and the scope of the operations had to be carefully adjusted to the limited available supplies of both food and water for men and animals.

The systematic tidal observations with self-registering tide-gauges, which were instituted under the superintendence of Major Baird, R.E., F.R.S., by the Government of India, in accordance with the recommendations of the British Association, have been continued at sixteen stations -including the ports of Aden, Kurrachee, Bombay, Madras, Calcutta and Rangoon, and Port Blair-completed at two stations, Kárwár and Pámban, and commenced at three new stations, of which two are on the Island of Ceylon, more under the direct influence of the Indian Ocean than the stations on the coasts of India. Good progress has been made with the lines of spirit-levels which are carried between the tidal stations, both along the coast lines and across the peninsula from coast to coast. So far as yet completed the operations indicate that the mean sea-level may be regarded as practically identical at all points on the open coast.

The Calcutta International Exhibition has necessitated a considerable extension of the operations of the lithographic and photographic offices under Colonel Waterhouse; the processes of heliogravure and collotype were found very serviceable in reproducing the delicate objects of Indian art-work which were exhibited. In the first of these processes a valuable improvement has been effected; originally the engraved copper plate was obtained by developing a positive pigment print, or relief in hardened gelatine, on a silvered copper plate, and then depositing copper upon it so as to form a new copper plate, bearing the design in intaglio, from which prints can be taken in the usual way. In the new process a negative pigment print is developed on a copper plate, and the intaglio image is obtained directly on the plate by biting in with a chemical solution, which penetrates the gelatine film comparatively easily in those parts representing the shadows of a picture or lines of a map, where there is little or no gelatine, biting the copper to a considerable depth; whereas in the parts representing the light of the picture or the ground of the map, where the gelatine is thicker, it penetrates with more and more difficulty as the tbickness of the gelatine increases, and in the highest lights should leave the copper untouched. The operation of biting does not take more than five minutes, and the engraved images are said to be marvellous in their delicacy of gradation and richness of effect. The great advantage of the process is its rapidity, a day or two being sufficient to prepare the etched plate, whereas from three weeks to a month are required to "deposit "a printing plate of sufficient thickness by photo-electrotyping ; on the other hand, it is difficult to get etching of sufficient depth to stand much printing without the loss of the finest tints.

The Report contains many other items of interest which our limits do not allow us to notice. It has evidently been compiled with much care, though there are occasional slips, as at page 3, where the country of Kafiristan is referred to as " an explorer in the service of the Educational Department," and the scale of the survey of that country is said to be "confidential." I. T. W.

\section{SCIENCE SCHOOLS AT HOME AND ABROAD}

$\mathrm{N}$ this volume Mr. Robins has collected together a series of communications which have appeared at various times in the Fournal of the Society of Arts and

I "Papers on Technical Education, Applied Science Buildings, Fittings, and Sanitation." By. Edward Cookwortny Robins. (London, I886.) 